DOI 10.15290/cnisk.2019.01.06.04

PROF. DR HAB. EWA MAJ

https://orcid.org/0000-0002-7295-1759

Uniwersytet Marii Curie-Skłodowskiej w Lublinie

\title{
Wzorzec parlamentarzystki w prasie dla kobiet w Polsce międzywojennej
}

\section{Streszczenie}

Prasa dla kobiet w Polsce międzywojennej była reprezentowana przez periodyki o różnorodnym zasięgu temporalnym i przestrzennym, częstotliwości wydawania, profilu światopoglądowym, a także sposobie pozycjonowania na rynku czytelniczym. Pełniła funkcję perswazyjna, dając wzorzec wychowawczy przeznaczony dla odbiorczyń, które miały rozmaite preferencje polityczne, prezentując pełny przekrój ideowy społeczeństwa polskiego. W kobiecym imaginarium znajdowały się postaci niezwykłe, godne naśladowania, pretendujące do miana „herosów w spódnicy”. Celem artykułu jest ukazanie medialnych wizerunków kobiet aktywnych politycznie pod kątem ich obecności w Sejmie Ustawodawczym 1919-1922 oraz w regularnym parlamencie Rzeczypospolitej Polskiej 1922-1939, ponadto w Sejmie Ślaskim 1920-1939.

Słowa kluczowe: prasa dla kobiet, wzorzec, parlamentarzystki, wizerunek medialny

\section{THE FEMALE PARLIAMENTARY MODEL IN THE WOMEN'S PRESS OF INTERWAR POLAND}

\begin{abstract}
The women's press in interwar Poland was represented by periodicals of varied temporal and spatial coverage, frequency of publishing, outlo-
\end{abstract}


ok profile, as well as the method of positioning in the press market. It had a persuasive role, presenting an educational model intended for recipients of various political preferences, overviewing the full ideological cross-section of Polish society. In the female imaginarium, there were extraordinary figures, worth following, aspiring to be called "heroines in skirts". The aim of the article was to present media images of politically active women in terms of their presence in the Legislative Sejm 1919-1922 and in the regular parliament of the Republic of Poland 1922-1939, and also in the Silesian Parliament of 1920-1939.

Keywords: women's press, model, member of parliament, media image

\section{Wstęp}

Obecność kobiet w polityce Polski międzywojennej nieustająco wzbudza zainteresowania badawcze ze względu na nadanie obywatelkom państwa praw wyborczych u progu niepodległości. Dekret Tymczasowego Naczelnika Państwa Józefa Piłsudskiego z 28 listopada 1918 r. dawał możliwość udziału w głosowaniu oraz kandydowania do Sejmu Ustawodawczego bez różnicy płci. Od tego czasu kobiety w II Rzeczypospolitej korzystały z czynnego i biernego prawa wyborczego $\mathrm{w}$ kampaniach lat 1919 (do Konstytuanty) oraz 1922, 1928, 1930, 1935, 1938. Łacznie w parlamencie międzywojennym były 32 posłanki i 7 senatorek, niektóre przez kilka kadencji z rzędu. Posłanki i senatorki Rzeczypospolitej Polskiej stanowiły około $2,5 \%$ całkowitej liczby reprezentantów ${ }^{1}$. $Z$ kolei w czterech kadencjach Śląskiego Sejmu Autonomicznego uczestniczyło 5 posłanek. Obok sprawy udziału obywatelek w naczelnych instytucjach publicznych istotna była kwestia upowszechniania wiedzy na ten temat w ówczesnym medium masowym, czyli w prasie. Dlatego przedmiotem zainteresowania w poniższym artykule stała się kwestia funkcjonowania periodyków „dedykowanych płci” oraz ich sposobów kreowania wzorców parlamentarzystek ${ }^{2}$.

1 Mariola Kondracka, Posłanki i senatorki II Rzeczypospolitej, (Warszawa : Wydawnictwo Sejmowe, 2017), 83; Kamil Kacperski, „Stulecie praw wyborczych kobiet w Polsce”, Infos, nr 12, 2018, 2.

2 M.Z. [Maria Zawialska], „Prasa kobieca”, w: Julian Maślanka (red.), Encyklopedia wiedzy o prasie, (Wrocław-Warszawa-Kraków-Gdańsk : Zakład Narodowy im. Ossolinskich, 1976), 172; Zofia Sokół, „Z badań nad polską prasą kobiecą w latach 1818-1939”, 
Identyfikacja prasy dla kobiet wiazała się z periodykami stereotypowo ukierunkowanymi na czytelniczki, a więc zawierającymi rubryki poradnictwa: opieki nad dzieckiem, kulinariów, trendów w strojach kobiecych i dziecięcych, dbania o urodę. Część z nich publikowała ponadto teksty o tematyce społecznej, ekonomicznej i kulturalnej, na ich łamach drukowane były wypowiedzi poświęcone polityce wewnętrznej państwa oraz sytuacji międzynarodowej. I właśnie ostatnia $z$ wymienionych kwestii dała podstawę do rozwiązania tytułowego problemu badawczego. Tym samym poza sfera zainteresowań znalazły się grupy periodyków typu: rodzinnego, branżowego (druków fachowych), szkolnego, „prasy serca”, majacej stylistykę sentymentalno-romansowa. Namysłu wymagało czasopiśmiennictwo o profilu światopoglądowym, a więc prasa religijna, także periodyki żeńskich zgromadzeń zakonnych. Ich treść w dużej mierze skoncentrowana na sprawach konfesyjnych ostatecznie skłoniła do rezygnacji $z$ dalszej eksploracji pod kątem poznania zagadnień mających wyraźnie polityczny charakter. Wyjątek stanowił miesięcznik Związku Sodalicji Mariańskich młodzieży szkół średnich zatytułowany „Pod Znakiem Marii”. Czasopismo sodalicyjne w odpowiedniej proporcji zawierało informacje o sytuacji społecznej w Polsce, co pozwoliło na umieszczenie go w bazie źródłowej. Ponadto wśród materiałów zakwalifikowanych do dalszej eksploracji obok regularnie wychodzących tygodników, miesięczników i kwartalników znalazły się dodatki stałe i okresowe, kalendarze, jednodniówki i inne druki okolicznościowe (głównie wyborcze) ukierunkowane na kobiety. Cechy czasopiśmiennicze miały biuletyny Narodowej Organizacji Kobiet (NOK) wydawane w latach 1925-1933 oraz sprawozdania Zwiazku Pracy Obywatelskiej Kobiet (ZPOK) za okres 1930-1933.

Procedura doboru źródeł sprawiła, że finalnej kwerendzie poddano próbę badawcza, na która złożyło się ponad dwadzieścia periodyków wyodrębnionych według kryterium reprezentatywności ze względu na wiek, wykształcenie, światopogląd, kondycję finansowa, status społeczny, po części także narodowość odbiorczyń. Podstawę dały czasopisma mające różne parametry częstotliwości publikacyjnej, czasu istnienia, profilu ideowego, aparatu nadawczego i odbiorczego. Pozyskano zestaw

Kwartalnik Historii Prasy Polskiej, t. 22, nr 3, 1983, 8; Kamilla Łozowska-Marcinkowska, Sprawy niewieście. Problematyka czasopism kobiecych Drugiej Rzeczypospolitej, (Poznań : Wydawnictwo Poznańskie, 2010), 6-11; Daria Domarańczyk, Od emancypacji do feminizmu. „Ster” jako postępowe pismo kobiece przełomu XIX i XX wieku, (Łódź : Wydawnictwo Primus Verbum, 2016), 8. 
periodyków o charakterze świadczacym o pełnej dyferencjacji ideowej i światopoglądowej i niemal kompletnym przekroju politycznym, a więc wyrażające idee: demokratyczne, katolickie, konserwatywne, liberalne, ludowe, nacjonalistyczne, narodowe, socjalistyczne, syjonistyczne. W wykazie znalazły się czasopisma nacechowane treścią feministyczną, ale też i druki umiarkowane przy formułowaniu postulatów egalitaryzmu politycznego. Efekty pracy eksploracyjnej przyniosła lektura pism jak: „Bluszcz”, „Ewa”, „Gazeta dla Kobiet”, „Gazetka dla Kobiet”, „Głos Kobiet” (socjalistyczny), „Głos Kobiet” (związkowy), „Głos Kobiety”, „Głos Polek”, „Głos Wielkopolanek”, „Hasło Polki”, „Jedynka”, „Kobieta Polska”, „Kobieta w Sejmie”, „Kobieta Wiejska”, „Kobieta Współczesna”, „Młoda Polka”, „Na Posterunku”, „Niewiasta Katolicka”, „Pani”, „Polka”, „Praca Obywatelska”, „Przegląd Kobiecy”, „Przodownica”, „Własnymi Siłami”, „Ziemianka Polska". Celem było pokazanie komponentów prasowych wizerunków parlamentarzystek $\mathrm{w}$ różnych ujęciach, ale $\mathrm{z}$ jednoznacznym motywem przewodnim w postaci posłannictwa edukacyjnego zgodnego $z$ wybranym systemem wartości politycznych.

W literaturze przedmiotu występował temat opiniowania parlamentaryzmu w prasie dla kobiet, prezentowano też osoby piastujące mandaty poselskie i senatorskie ${ }^{3}$. Ponadto użyteczne były odniesienia do wątków ofensywnej propagandy w prasie politycznej, gdy zespół redakcyjny zajmował się zagadnieniami praw kobiet i ich realizacji $\mathrm{w}$ instytucjach przedstawicielskich, a nade wszystko wykazywał umiejętność aranżowania i prowadzenia kampanii prasowych. W toku eksploracji materiałów źródłowych wykorzystana została metoda analizy tekstów prasowych w kontekście sytuacyjnym i $z$ wykorzystaniem teorii perswazji ${ }^{4}$. Kwerendzie prasy towarzyszyła hipoteza dotycząca występowania dwóch wyrazistych podejść publicystyki politycznej do tytułowego problemu: po pierwsze, że koncentrowano się na cechach parlamentarzystek determinowanych przez płeć (kody płci), po drugie, że zwrócono uwagę na próby

\footnotetext{
3 Waldemar Barszczewski, „Kwestia parlamentarna w polskich czasopismach kobiecych w latach dwudziestych i trzydziestych XX wieku”, w: Małgorzata Dajnowicz, Adam Miodowski (red.), Polityka i politycy w prasie XX i XXI wieku, (Białystok : Wydawnictwo Humanica, 2016), 318-327.

4 Walery Pisarek, „Perswazja - jak ją widza, jak ją pisza”, w: Katarzyna Mosiołek-Kłosińska, Tadeusz Zgółka (red.), Język perswazji publicznej, (Poznań : Wydawnictwo Poznańskie, 2003), 15; Irena Tetelowska, Szkice prasoznawcze, wybór rozpraw i artykułów Paweł Dubiel, Walery Pisarek, (Kraków : Ośrodek Badań Prasoznawczych RSW „Prasa”, 1972), 194-196.
} 
stosowania przez posłanki i senatorki innowacyjnych sposobów realizacji misji społecznej w trakcie wypełniania obowiązków legislacyjnych (kody władzy). Jej weryfikacji poświęcono poniższy tekst ujęty w trzyelementowy zestaw zagadnień dotyczących wybranych elementów komunikacji kobiecej (female communication), ale też właściwości wizerunków parlamentarzystek w odniesieniu do tradycyjnie pojmowanej kobiecości oraz form ekspresji politycznej pań, które osiagnęły sukces w walce o mandaty instytucji przedstawicielskich.

\section{Komponenty female communication}

Prasa dla kobiet znajdowała się w systemie mediów w państwie polskim, przynależąc do zbioru ,instytucji organizacji bioracych udział w różny, właściwy sobie sposób - w procesie masowego komunikowania międzyludzkiego o charakterze periodycznym” oraz tworząc „najdynamiczniej rozwijająca się grupe prasowa”5. Była częścią instytucjonalnego procesu komunikacji społecznej, kreowała mikroprzestrzeń nacechowaną istotnymi watkami politycznymi. Wzmiankowane powyżej tytuły prasowe dały pole do ekspozycji zwiąków $z$ konkretnym systemem wartości politycznych w szerokim spektrum ideowym i światopoglądowym. Redaktorki i dziennikarki prasy dla kobiet dażyły do: kształtowania relacji z czytelniczkami, przeciwdziałania dyskredytacji i infantylizacji pracy kobiet, kreowania i umacniania potencjału politycznego tkwiącego w działaniach kobiet, zorientowania czytelniczek na pragmatyczne podejście do spraw stereotypowo powiazanych $z$ kobietami. Stosowały strategie korzyści w postaci zdobywania specjalistycznej wiedzy, kształtowania poczucia więzi, stymulowania tożsamości płciowej. W ramach strategii korzyści kreowały i upowszechniały wzorcowe wizerunki parlamentarzystek $\mathrm{z}$ przesłaniem, że

\footnotetext{
5 Jolanta Chwastyk-Kowalczyk, „Bluszcz” w latach 1918-1939. Tematyka społeczna oraz problemy kultury i literatury, (Kielce : Wydawnictwo Akademii Świętokrzyskiej, 2003); Marzena Lizurej, „Prasa kłamie czy wychowuje? Fenomen prasy kobiecej”, w: Witold Jakubowski, Edyta Zierkiewicz (red.), Edukacyjne konteksty kultury popularnej, (Kraków : Impuls, 2002), 75; Inga Iwasiów, Aleksandra Krukowska, Agata Zawiszewska (red.), Nowa Kobieta-figury i figuracje, (Szczecin : Wydawnictwo Naukowe Uniwersytetu Szczecińskiego, 2017), 216; Krzysztof Kaszewski, Media o sobie. Językowe elementy autopromocyjne w przekazach informacyjnych prasy, radia i telewizji, (Warszawa : Wydawnictwo Naukowe Semper, 2018), 23.
} 
przed bojownica dzisiejszą i jutrzejszą otwierają się nowe pola działania - szerokie, bo obejmujące naród cały, którego jako wyborczynie, posłanki, senatorki, radne stały się przedstawicielkami ${ }^{6}$.

Szczególną korzyścią było sięganie do pisarstwa publicystycznego posłanek i senatorek, które występując w podwójnej roli twórczyń komunikatów politycznych oraz uczestniczek procesu ich transmisji, dawały świadectwo pracy parlamentarnej z punktu widzenia własnych doświadczeń. W tym gronie znalazły się parlamentarzystki, które zarówno w okresie przed kandydowaniem do instytucji przedstawicielskich, jak i w toku sprawowania mandatu miały dorobek redaktorski, wydawniczy, publicystyczny. Współorganizowały redakcję organów partyjnych, jak Irena Kosmowska („Wyzwolenie - dawniej Polska Ludowa”) czy Zofia Praussowa („Trybuna”), bądź czasopism specjalistycznych, jak Regina Danysz-Fleszarowa („Bibliografia Geologiczna Polski”, „Ziemia. Dwutygodnik Krajoznawczy”), kierowały periodykami profilowanymi światopoglądowo, jak Janina Omańkowska (tygodnik „Gwiazda” dla ludu polsko-katolickiego na Śląsku oraz „Dodatek do Górnoślązaka”) bądź Janina Kirtiklisowa („Znicz”). Najczęściej jednak miały doświadczenie przy kierowaniu redakcjami czasopism dla kobiet: Zofia Daszyńska-Golińska („Na Posterunku”), Dorota Kłuszyńska („Głos Kobiet”), Wanda Ładzina („Kalendarz Pani Domu na Wsi i w Mieście” - wraz z Zofią Zaleska), Maria Moczydłowska („Głos do Kobiet Wiejskich”), Zofia Praussowa („Głos Kobiet”), Milena Rudnicka („Gromadjanka”, „Żinka”), Halina Stęślicka („Głos Polek”), Franciszka Wilczkowiakowa („Głos Kobiety”), Zofia Zaleska („Gazetka dla Kobiet”, „Życie Kobiet”, „Współczesne Życie”, „Współczesne Życie Kobiet") ${ }^{7}$. Ponadto dorobek publicystyczny miały m.in.: Gabriela Balicka, Jadwiga Dziubińska, Maria Holder-Eggerowa, Róża Melcer, Zofia Moraczewska, Ewelina Pepłowska, Irena Puzynianka, Zo-

\footnotetext{
6 Cecylia Walewska, „O równe prawa”, Kobieta Współczesna, nr 18, 1927, 5; zob.: Joanna Szyszko-Trojanowska, "Nasze zdobycze i nasze zaniedbania” - Cecylia Walewska o instynkcie społecznym", w: Agata Siwiec, Joanna Szyszko-Trojanowska, Agata Zaliszewska (red.), Modele aktywności politycznej Polek od XIX do XXI wieku, (Szczecin : Wydawnictwo Naukowe Uniwersytetu Szczecińskiego, 2018), 41-56. Pojęcie „bojownice” należało do słów sztandarowych stosowanych przy opisach poczynan kobiet, szczególnie wówczas, gdy odniosły sukces. Mieściło w sobie symbolikę polityczna, zawierało kody etyczne, hierarchizowało wartości według wybranego porządku aksjologicznego; Walery Pisarek, Polskie słowa sztandarowe $i$ ich publiczność, (Kraków : Universitas, 2002), 11-12.

7 Zofia Zaleska, Czasopisma kobiece w Polsce. (Materiały do historii czasopism). Rok 1818-1937, (Warszawa : Wyższa Szkołą Dziennikarska, 1938), 7 i n.
} 
fia Sokolnicka, Józefa Szebeko, Bronisława Szymkowiakówna ${ }^{8}$. Należały do różnych kręgów politycznych, które - przy rozmaitości odcieni ideowych i światopoglądowych - układały się w dychotomiczny porzadek wyrazistych bloków: lewicy (postępowości) i prawicy (zachowawczości) ${ }^{9}$. Polityczne bloki nie miały jednak cech bezwzględnej trwałości, co więcej - uległy przewartościowaniu po przewrocie majowym wraz z tworzeniem formuły bezpartyjnej „sanacyjnej obywatelskości”, niwelującej wcześniejszą konwencję klarownego systemu pluralizmu politycznego.

Doświadczenie prasowe parlamentarzystek wzbogacało wiedzę na temat kreowania wizerunków politycznych, ponieważ dokumentowały one wyniki własnej pracy sejmowej, opiniowały działalność koleżanek $z$ ław parlamentarnych, a nade wszystko przedkładały wiedzę o sytuacji politycznej kobiet. Autorskie materiały wyróżniały się wiarygodnością i autentyzmem, miały konkretną formułę nadawcza, gdyż w podpisie umieszczano informację dopełniająca „poseł na Sejm”, a nadto prezentowały problematykę znana im $z$ bezpośredniej obserwacji. Formuła nosce te ipsum („poznaj samego siebie”) była stosowana celem: (1) kreowania obrazu tożsamości parlamentarzystek, (2) gruntowania wiedzy o ich pracy parlamentarnej, (3) zwiększenia wiarygodności przekazu prasowego, (4) uświadomienia i pozyskania elektoratu kobiecego. Cel ich zaangażowania medialnego miał raczej illokucyjny charakter, wynikający z czynności informowania, perswadowania, ostrzegania czytelniczek. Skoro mowa o tożsamości dziennikarskiej, wypada zauważyć, że w materiałach wyborczych kandydatki dokonywały aktu samoidentyfikacji, stosując określenie „publicystka”, co oznaczało, że - podobnie jak ich koledzy -

\footnotetext{
8 Joanna Dufrat, „Buntowniczka w Sejmie. Parlamentarna aktywność Zofii Moraczewskiej (1873-1958)", w: Szczepan Kozak et al. (red.), Człowiek, społeczeństwo, źródło. Studia dedykowane profesor Jadwidze Hoff, (Rzeszów : Wydawnictwo Uniwersytetu Rzeszowskiego, 2014), 99-107; Katarzyna Luksa, Gabriela Balicka (1867-1962). Działalność polityczna, społeczna, naukowa, edukacyjna, (Warszawa : Wydawnictwo Sejmowe, 2017); Grażyna Wyder, „Wielkopolskie działaczki w ruchu narodowo-demokratycznym na terenie Poznańskiego na przełomie XIX i XX wieku. Szkic do działalności politycznej kobiet”, Czasopismo Naukowe Instytutu Studiów Kobiecych, nr 1, 2017, 58-67.

9 Michał Śliwa, „Wzorzec osobowy kobiety - socjalistki w Polsce”, w: Anna Żarnowska, Andrzej Szwarc (red.), Kobiety i edukacja na ziemiach polskich w XIX i XX wieku, t. 2, cz. 1, (Warszawa : Instytut Historyczny Uniwersytetu Warszawskiego, 1995), 231-232; Ewa Maj, „Parlamentarzystki Narodowej Demokracji”, w: Urszula Kozłowska, Tomasz Sikorski, Adam Wątor, Obywatelki na obcasach. Kobiety w życiu publicznym (XIX-XXI w.), (Radzymin-Warszawa : Wydawnictwo von Borowiecky, 2016), 131-146.
} 
doceniały znaczenie pisarstwa użytkowego ${ }^{10}$. Notabene udowodniły, że znały techniki wpływu na odbiorców, m.in. zwracając uwagę na populistyczne chwyty komunikacyjne stosowane w działaniach politycznych ${ }^{11}$.

Parlamentarzystki posługujące się warsztatem publicystycznym stosowały techniki informacyjno-afirmatywne, upowszechniając wiedzę o zasługach posłanek i senatorek. Przykład dała Halina Stęślicka, która przybliżała czytelniczkom poczynania Gabrieli Balickiej. Jej zdaniem Balicka w Sejmie Ustawodawczym

miała obowiazek czuwania nad tym, aby konstytucja nasza oparta była na zasadach słuszności i sprawiedliwości oraz zawierała w głównych zarysach te zasady, na których zgodnie $z$ naszymi ideałami winien opierać się ustrój Polski katolickiej i narodowej ${ }^{12}$.

Filiacje prasowe obu posłanek były podbudowane wspólnota wartości politycznych o charakterze narodowym i katolickim, a także przynależnością organizacyjna - obie należały do NOK - oraz aktywnością na rzecz ochrony kobiet przed skutkami dyskryminacji prawnej i obyczajowej. Różniły je cechy demograficzne, jak wiek (Balicka ur. 1867; Stęślicka ur. 1897), wykształcenie (Balicka uzyskała stopień naukowy doktora na uniwersytecie w Genewie; Stęślicka miała za sobą niedokończone studia we Wrocławiu, następnie w Krakowie), kompetencje parlamentarne (Balicka nieprzerwanie sprawowała mandat poselski w latach 1919-1935; Stęślicka miała dorobek poselski wyłącznie w parlamencie I kadencji). Istotne okazały sie jednak atrybuty socjopolityczne (Polka-katoliczka), decydujące przy tworzeniu przez Stęślicka medialnego wizerunku starszej i bardziej doświadczonej koleżanki. Jej publicystyczne refleksje miały charakter rejestracji walki Balickiej o ustawowe regulacje praw kobiet.

Pod względem genologicznym materiały prasowe poświęcone parlamentarzystkom bądź przez nie sporządzone cechowały się różnorodnością gatunkową. Na łamach tygodników i miesięczników druko-

\footnotetext{
10 Mariola Kondracka, Posłanki, 134; Ewa Maj, „Politycy - publicyści prasowi w Polsce”, w: Małgorzata Dajnowicz, Adam Miodowski (red.), Polityka i politycy $w$ prasie XX i XXI wieku, 167-182.

11 Stefania Tatarówna, „Na przełomie”, Głos Wielkopolanek, nr 5, 1924, 1-2; Stefania Podhorska-Okołów, „Przed nową próbą sił”, Bluszcz, nr 1, 1928, 1; „Ruch kobiecy”, Gazeta dla Kobiet, nr 4, 1928, 38; „Rozrzućmy we wrześniu "Młodą Polkę" - tysiącami”, Młoda Polka, nr 7, 1939, 100.

12 Halina Stęślicka, „Ze zjazdu Związku Kobiet Pracujących w Gnieźnie w 1924 roku (wyjątek z mowy poselskiej)", Gazeta dla Kobiet, nr 7, 1924, 3.
} 
wano artykuły ogólnoinformacyjne i specjalistyczne, sporządzano notatki i wzmianki, przeprowadzano wywiady, ponadto pojawiały się listy otwarte $^{13}$. Wywiady $z$ kobietami, które odniosły sukces zawodowy, miały charakter rozmów poświęconych konkretnym tematom. Cechował je profesjonalizm, a od interlokutorek oczekiwano wiadomości o procesach instytucjonalizacji ruchu kobiecego i rytualizacji pracy parlamentarnej. Dziennikarki unikały potoczności, eliminowały przejawy emocjonalnego podejścia do poruszanych zagadnień na rzecz akcentowania merytorycznej rangi wywiadu. Dramaturgia dialogu z parlamentarzystka dawała szansę na spowodowanie reakcji czytelniczek i kontynuowania tematyki rozmowy w kolejnych numerach pisma.

Prasa tworzyła istotną agendę uprawomocnienia obecności kobiet w sferze publicznej. Wspomniane uprzednio poczucie misyjności zawo$\mathrm{du}$ dziennikarki/parlamentarzystki wiązało się z posługiwaniem sugestywną metaforyką powołania do służby innym kobietom i nieustajacym manifestowaniem zaangażowania w sprawy płci. Publicystki prasy dla kobiet zabiegały o to, by czytelniczki otrzymywały stosowną wiedzę, która kształtowała ich tożsamość społeczną oraz integrowała ze środowiskiem „bojownic” i „herosów w spódnicy”. Skłaniano do redefiniowania uczestnictwa w interakcjach społecznych w duchu proobywatelskim czy pronarodowym ${ }^{14}$. Duża część czynności związanych $z$ kształtowaniem wzorcowego wizerunku parlamentarzystek dotyczyła uzasadnienia powodów, dla których kobiety miały prawo ubiegać się o równouprawnienie. Par-

13 Zob.: Helena Ceysingerówna, „O poczuciu obowiązku obywatelskiego. Wywiad z senatorką dr Zofią Daszyńską-Golińską”, Kobieta Współczesna, nr 25, 1928, 4-5; „Przed wyjazdem do Genewy. Wywiad z p. senatorką Józefą Szebekówna”, Kobieta Współczesna, nr 6, 1927, 5-6; „Nowe posłanki i senatorki”, Kobieta Współczesna, nr 52, 1930, 19-21; „Do posłanek BBWR. List otwarty”, Kobieta Współczesna, nr 1, 1931, 14. Na temat gatunków prasowych zob.: Maria Wojtak, „Interakcyjny styl komunikowania w prasie kobiecej”, w: Eadem, Rozłożone gazety. Studia z zakresu prasowego dyskursu, języka i stylu, (Lublin : Wydawnictwo Uniwersytetu Marii Curie-Skłodowskiej, 2015), 107.

${ }_{14}$ W periodyku dla katoliczek tłumaczono: „słychać słowa, że kobietom bardziej do twarzy $z$ warzechą i $z$ dzieckiem, niż z organizacją, ale świadoma kobieta powinna czynnie angażować się w pracę instytucji chroniących Polskę przed immoralizmem. Ogłaszano: "Cześć Matronom, które kroczą śmiało w szeregach katolickich, a przez to inne niewiasty porywają za sobą i zachęcaja je do naśladownictwa”, „Jubileusz Niewiast Katolickich w Jabłonkowie", Niewiasta Katolicka, nr 7, 1931, 3. W kręgach socjalistycznych formułowano program rozwoju samoświadomości kobiet i pobudzenia obywatelek Polski do aktywności dla dobra ogółu, zob.: Ewa Maj, „Kobieta wobec polityki; strategie tożsamościowe w publicystyce tygodnika "Na Posterunku" (1917-1919)", w: Małgorzata Dajnowicz, Adam Miodowski (red.), Polityka i politycy $w$ prasie XX $i$ XXI wieku. Polityka $w$ prasie kobiecej, (Białystok : Wydawnictwo Uniwersytetu w Białymstoku, 2019), 43-56. 
lamentarzystki o poglądach konserwatywnych i narodowo-katolickich pisały o równości motywowanej normami chrześcijańskimi. Natomiast w szeregach socjalistycznych i liberalnych powoływały się na równość uwarunkowana prawami człowieka i obywatela oraz doświadczeniami równoprawnych warunków życia zadekretowanymi w systemach prawnych innych państw. Tłumaczyły, że sukcesy polityczne poszczególnych komitetów wyborczych były uzależnione od głosowania kobiet ${ }^{15}$.

W wizerunek wkomponowane były czynności użyteczne dla edukacji obywatelskiej, jak wiedza o ordynacji wyborczej. Przyuczano do zachowań propaństwowych, by kobiety świadomie głosowały, wybierajac kandydatki z konkretnej przestrzeni aksjologicznej. Czytelniczki otrzymywały informacje o danych personalnych wraz z syntetycznymi wiadomościami o osobach ubiegających się o mandat poselski czy senatorski. Zachęcano je do rozważnego wyboru, żeby przeciwdziałać „ślepocie umysłowej i duchowej". Niektóre wypowiedzi brzmiały zdecydowanie, gdy przykładowo przed wyborami 1922 r. publicystka centroprawicowego tygodnika "Głos Wielkopolanek" nawoływała do pełnej mobilizacji elektoratu kobiecego, ponieważ „prawa się bierze, nikt ich nie daje. Bierze się siłą muskułów, siła pięści, bierze się tyle, na ile nas stać, aby umieć utrzymać je” ${ }^{16}$. Z kolei w 1928 r. w socjalistycznym periodyku „Głos Kobiet” senatorka Dorota Kłuszyńska tłumaczyła: „Przecież już dwukrotnie kobiety głosowały i zawsze na swoich wrogów. Dotychczasowe gorzkie doświadczenia muszą otworzyć oczy nawet najmniej politycznie wyrobionym kobietom”17. Przekonywała, że „oszukiwano je hasłami o Bogu i Ojczyźnie. Oszukiwano, wyzyskiwano ich dobra wiarę, że ludzie bogaci

15 „O równe prawa dla kobiet”, Gazeta dla Kobiet, nr 26, 1918, 104; Zofia Daszyńska-Golińska, „Tereny doświadczalne parlamentarnej pracy kobiet”, Na Posterunku, 1917, nr 21, 1-2; „Kronika działalności kobiecej”, Bluszcz, nr 51, 1918, 387; Dorota Kłuszyńska, „Udział kobiet w zwycięstwie wyborczym PPS”, Głos Kobiet, nr 4, 1928, 32; zob.: Joanna Dufrat, „Dyskusje wokół "nowego typu kobiety-obywatelki” w Drugiej Rzeczypospolitej”, w: Anna Landau-Czajka, Katarzyna Sierakowska (red.), Procesy socjalizacji w Drugiej Rzeczypospolitej 1914-1939. Zbiór studiów, (Warszawa : Instytut Historii PAN, 2013), 107; Jolanta Chwastyk-Kowalczyk, „Próby uobywatelnienia kobiet w okresie dwudziestolecia międzywojennego na łamach "Bluszczu", w: Małgorzata Dajnowicz, Adam Miodowski (red.), Polityka i politycy $w$ prasie XX $i$ XXI wieku. Polityka $w$ prasie kobiecej, 75-102.

16 Olga Milewska, „Pójdź - jesteś potrzebna”, Głos Wielkopolanek, nr 39, 1922, 4; Stefania Tuchołkowa, „Udział kobiety w polityce”, Głos Wielkopolanek, nr 44, 1922, 1-4; „Nasi kandydaci”, Głos Wielkopolanek, nr 42, 1922, 1; Felicja Żurawska, „Otwarte oczy”, Jednodniówka Młodej Polki, [1934], 1.

17 Dorota Kłuszyńska, „Wyborczynie, w waszych rękach zwycięstwo”, Głos Kobiet, nr wyborczy, 1928, 2. 
mogą dopomóc biednym, jeżeli będą mieli władzę"18. Zrozumiałe było, że z kolei redakcja katolickiego pisma "Gazeta dla Kobiet” przypominała: „szanująca się kobieta - będzie dbała o to, żeby w partii mej zasiadali nie tylko posłowie, lecz żeby z niej posłowały także zacne katoliczki, kobiety-posłanki"19. Natomiast dwa lata później zalecała, aby

wybierać na posłów dobrych katolików, dających pewność, że stać będa na straży zasad i praw Kościoła katolickiego, wnosić wedle warunków i możności ducha i zasady Chrystusowe do szkoły, wojska, urzędów państwowych, gminnych, a zwłaszcza do uchwalonych przez sejm ustaw ${ }^{20}$.

Zmiany prawa wyborczego w ostatnich wyborach parlamentarnych w Polsce międzywojennej sprawiły, że prasa dla kobiet stosunkowo niewiele uwagi poświęcała kwestii kandydowania do Sejmu RP, a prawie całkowicie pomijała obsadę izby wyższej. Znamienna była wypowiedź Z września 1938 r. o tym, że

ordynacja wyborcza do Senatu ograniczyła prawo głosowania kobiet do minimum. O ile kobieta nie posiada orderów, ukończonej szkoły wyższej lub zawodowej i seminarium nauczycielskiego oraz nie jest czynną nauczycielka, nie będzie mogła być wyborczynią do Senatu. Wybory odbędą się 15 września br. Szczegółów nie podajemy, ponieważ znikoma ilość naszych Czytelniczek ma prawo głosu do Senatu ${ }^{21}$.

Prasa dla kobiet wykreowała przestrzeń o jednorodnych cechach medialnych i zróżnicowanych parametrach technicznych, ideowych, doktrynalnych. Spełniała społeczne oczekiwania na publikację tematów „dedykowanych płci”, w tym problemu uczestnictwa w pracach naczelnych instytucji państwowych, przekonujac czytelniczki, że „dobre pismo, to przyjaciel twój i twoich najbliższych"22. Reguły female communication realizowane $\mathrm{w}$ toku kształtowania wizerunków parlamentarzystek da-

\footnotetext{
18 Ibidem; zob. Aneta Dawidowicz, „Problematyka polityki i polityków na łamach "Głosu Kobiet", czasopisma dla kobiet wydawanego w latach 1908-1939”, w: Małgorzata Dajnowicz, Adam Miodowski (red.), Polityka i politycy w prasie XX i XXI wieku. Polityka w prasie kobiecej, 57-71.

19 „Rozważania przedwyborcze”, Gazeta dla Kobiet, nr 2, 1928, 15.

20 „Sprawozdanie z 24 Zjazdu Delegowanych Stowarzyszeń Zwiazku Kobiet Pracujących w dniu 1 czerwca 1930 r. w Poznaniu", Gazeta dla Kobiet, nr 10, 1930, 96.

21 „Wybory”, Gazeta dla Kobiet, nr 9, 1935, 69.

22 Własnymi Siłami. Miesięcznik dla kobiety katolickiej, nr 1, 1939, 6.
} 
wały podstawy do ustalenia okoliczności tworzenia grupy i jej kultury z zaznaczeniem, że komponenty grupy poza cechami demograficznymi (płeć) podlegały dyferencjacji, tak jak parlamentarzystki różniły się między soba pod względem światopoglądu, katalogu wartości politycznych, przynależności partyjnej. Natomiast można było znaleźć wspólnotę postaw prospołecznych, ponieważ niemal wszystkie parlamentarzystki były zaangażowane w działalność oświatowa, kulturalna, opiekuńczą, co wywodziło się jeszcze z czasów przed 1918 r., kiedy różnego rodzaju formy „pracy organicznej” i „pracy u podstaw” należały do składników dorobku biograficznego Polek.

\section{Wzorzec kobiecości - kody płci}

Archetypy kobiecości ujawniały się podczas pokazywania parlamentarzystek jako osób, które miały bogate i pełne doświadczenia życie rodzinne, koleżeńskie, towarzyskie, ponieważ „do dzisiejszego ustroju społecznego musimy stworzyć nowy typ kobiety, który nie zatracając cech kobiecości, potrafi zająć każde miejsce w społeczeństwie"23. Powyższe stwierdzenie pochodziło $z$ łamów tygodnika „Ziemianka Polska”, co oznaczało, że redaktorki i publicystki ze środowiska konserwatywnego i narodowo-katolickiego widziały potrzebe kształtowania wizerunku nacechowanego właściwościami typowymi dla płci, ale też planowały uczestnictwo w kreacji wizerunku zmodernizowanego. W podobnym tonie wypowiadały się redaktorki o poglądach lewicowych, gdy wypowiadały się o nieuchronności procesów emancypacyjnych kobiet ${ }^{24}$. Przekonywały, że rychła i kompletna socjalizacja prowadziła do zajęcia się sprawami wykraczającymi poza mikroświat domu, kuchni, pokoju dziecięcego. W toku kształtowania wzorca parlamentarzystki uwidoczniła się dążność do binarnego ujmowania kwestii w postaci (1) neutralizowania obecności mitu kobiety-gospodyni czy kobiety-pani domu w prasie socjalistycznej

23 Z.Z., „W zjednoczeniu siła i podpora”, Ziemianka Polska, nr 23, 1930, 6.

24 Sylwia Bujak-Boguska, Na straży praw kobiety. Pamiętnik Klubu Politycznego Kobiet Postępowych 1919-1930, (Warszawa : bw, 1930), 25. 
i liberalnej25; (2) modernizowania mitu kobiety-żony i kobiety-matki w prasie konserwatywnej, narodowej, katolickiej ${ }^{26}$.

Koncentrowanie się na wzorcach parlamentarzystek było elementem szerszej aktywności dziennikarek uczestniczących w zjawisku polityzacji sfery prywatnej w kontekście upowszechnienia wiedzy o nierówności społecznej kobiet, szkodliwej dla interesów ogółu. Takie działania wiązały się $z$ dążnością do zerwania $z$ podziałem na sprawy prywatne - kobiece oraz sprawy publiczne - męskie. Publicystki dążyły do uwypuklenia perspektywy podmiotowej, dlatego pokazywały konkretne parlamentarzystki, tworząc swego rodzaju suplementy do prasowych obrazów aktywności męskiej, by choć w części zrównoważyć medialną obecność posłów i senatorów. Parlamentarzystkom a priori przypisywane były konkretne właściwości, które miały sprawdzoną użyteczność w procesie wypełniania posłannictwa edukacyjnego.

Niezależnie od nadmienionych rozbieżności ideowych pojawiała się wspólnota wyobrażeń o parlamentarzystkach kultywujących cechy typowe dla płci. Znalazły się odniesienia do kobiecości interpretowanej jako kwintesencja pożądanych cech osobowościowych. Właściwości ze sfery prywatnej były transferowane do wizerunku przynależnego sferze publicznej. Kobieta umiejacca zrobić karierę w świecie polityki była godna podziwu, a jej cechy stawały się komponentami ideału wychowawczego. Była: altruistyczna, cierpliwa, dzielna, energiczna, obowiąkowa, oddana, odpowiedzialna, opanowana, pracowita, praktyczna, pryncypialna,

25 Paulina Appenszlakowa, „Cel w życiu (Kilka słów o "ideale zamążpójścia»”, Ewa, nr 11, 1928, 1; zob.: Eva Plach, „Feminizm and Nationalism on the Pages of Ewa: Tygodnik, 1928-1933", Polin. Studies in Polish Jewry, vol. 18, 2005, 241-262; Anna Landau-Czajka, „Kobiety na pograniczu polsko-żydowskim (żydowska prasa polskojęzyczna)”, w: Tomasz Pudłocki, Katarzyna Sierakowska (red.), Aktywność publiczna kobiet na ziemiach polskich. Wybrane zagadnienia, (Warszawa : Wydawnictwo Neriton, 2013), 157-168; Por. Joanna Lisek, „Dyskurs feministyczny w kobiecej prasie jidysz w Polsce”, Pamiętnik Literacki, z. 4, 2008, 61-77. Korekta mitu tradycyjnej roli kobiety następowała przy użyciu technik promowania stylu życia prozdrowotnego: Zofia Zaleska, „Obozownictwo jako sport”, Bluszcz, nr 34, 1928, 3-4; Aniela Zdanowska, „O zdrowiu”, Przodownica, nr 2, 1931, 9-10; zob. Joanna Szyszko-Trojanowska, „Równouprawnienie sportowe a kształtowanie się nowego typu kobiety sportsmenki w świetle międzywojennych magazynów dla kobiet - "Bluszczu" i «Startu»", w: Inga Iwasiów, Aleksandra Krukowska, Agata Zawiszewska (red.), Nowa Kobieta-figury i figuracje, (Szczecin : Wydawnictwo Naukowe Uniwersytetu Szczecińskiego, 2017), 287-311.

${ }^{26}$ „O powrót kobiety-matki do ogniska domowego”, Gazeta dla Kobiet, nr 6, 1933, 1; „Wiadomości Zarzadu Sekretariatu Generalnego”, Gazeta dla Kobiet, nr 1, 1923, 1; „Stanowisko kobiet w różnych narodach", Niewiasta Katolicka, nr 5, 1931, 4; Wanda Żebrowska, „Do Czytelniczek”, Przodownica, nr 15, 1931, 117-119. 
rozsadna, rygorystyczna, rzetelna, silna, skromna, skrupulatna, skuteczna, sprawiedliwa, stanowcza, staranna, sumienna, troskliwa, wrażliwa, wspaniałomyślna, wytrwała, zapobiegliwa, zaradna, zatroskana, zdecydowana, życzliwa. Zestaw słów pochodził $z$ lektury tygodników dla kobiet. Stanowił spuściznę dziewiętnastowiecznego wizerunku kobiety, petryfikowanego na użytek współczesnej odbiorczyni przekazu prasowego ${ }^{27}$. Zawierał katalog sprzecznych ze sobą cech, ale był zgodny $z$ niektórymi przejawami egzaltacji w opisie osobowości parlamentarzystek, gdy charakteryzując posłankę, napisano:

Jest ona Strażniczką Ognia, do którego raz po raz dorzuca płomienne bursztyny ofiary i wszystkie palne materiały goracych serc kobiecych, oddane jej z zaufaniem do rozporządzenia ${ }^{28}$.

Kody płci stawały się użyteczne, gdy uzasadniane były prawa do równej partycypacji w życiu publicznym. Akcentowano atrybuty kobiecości ujętej hasłowo jako „entuzjazm, optymizm i dobroć”, ale też w opisach poczynań parlamentarzystek wzmiankowano o ich praktyczności, pozwalającej usytuować działania pań ponad poczynaniami męskimi. Wspomniane cechy identyfikowane $z$ kobiecością o pozytywnej konotacji miały przechylić szalę zwycięstwa na rzecz uprawomocnienia obywatelek i dopuszczenia do udziału w ośrodkach decyzji politycznych. Wskazywano, że potrafilyby one efektywnie działać na rzecz dobra wspólnego, dlatego powinny mieć miejsce $\mathrm{w}$ parlamencie. Przy prasowej prezentacji sylwetek posłanek i senatorek pojawiały się głosy nieufności wobec polityki uprawianej przez mężczyzn: „Nie łudźmy się, że wielcy mężowie

${ }^{27}$ Krzysztof Jakubiak (red.), Partnerka, matka, opiekunka. Status kobiety $w$ dziejach nowożytnych od XVI do XX wieku, (Bydgoszcz : Wydawnictwo Uczelniane Wyższej Szkoły Pedagogicznej, 2000); Jerzy Franke, Wokót buntu i pokory. Warszawskie czasopisma kobiece w latach 1905-1918, (Warszawa : Instytut Informacji Naukowej i Studiów Bibliologicznych Uniwersytetu Warszawskiego, 2000); Renata Bednarz-Grzybek, Emancypantka i patriotka. Wizerunek kobiety przełomu XIX i XX wieku w czasopismach Królestwa Polskiego, (Lublin : Wydawnictwo Uniwersytetu Marii Curie-Skłodowskiej), 2010; Teresa Kulak, „Czerwone bluzki” w akcji. Krakowski Zjazd Kobiet polskich w październiku 1905 r. w walce o prawa społeczne i obywatelskie", w: Teresa Kulak, Agnieszka Chlebowska (red.), Kobiety w wojnach $i$ konfliktach polityczno-społecznych na ziemiach polskich $w$ pierwszej połowie XX wieku. Wybrane zagadnienia, (Wrocław : Wydawnictwo Chronicon, 2014), 30.

28 „Nasze kandydatki”, Jedynka. Organ Komitetu Wyborczego Organizacji Kobiecych, nr 2, 1930, 2. W winiecie tygodnika "Gazeta dla Kobiet” (numer zwiazkowy) znajdowało się motto, które dezawuowało negatywne wypowiedzi o emocjonalnej stronie osobowości kobiety, że „Serce kobiety nie jest tak słaba podpora, jak myślą ci, co go nie warci...”. 
świata potrafia doprowadzić państwa do rozbrojenia"29. Dość dobitnie brzmiało stwierdzenie, że „głupi, niedołężny mężczyzna ma wszystkie prawa i wszystkie przywileje, a mądra, energiczna, silna kobieta łamie się pod pręgierzem zakazów prawnych, społecznych, obyczajowych" ${ }^{30}$. Wreszcie sarkastycznie pytano:

komu należy się rząd świata: kłótliwemu, zadzierzystemu, wiecznemu rewolucjoniście mężczyźnie, czy karnej, posłusznej, wiernej (modzie) kobiecie? Wiem z góry, jaki będzie wynik plebiscytu, i ręczę, że światu wyjdzie na dobre rączka kobiety, która zawsze tak wdzięcznie dzierżyła parasolkę, wachlarz, torebkę, a $\mathrm{z}$ taka sama elegancja ujmie w swe dłonie tekę ministerialną ${ }^{31}$.

Cechy płci pozwalały zatem na legitymizowanie żądań egalitaryzmu politycznego nawet przy stereotypowym ujmowaniu kobiecości w kontekście domniemanej emocjonalności pań:

Wszyscy twierdza, i mężczyźni także to mówią, że kobiety sa uczciwsze i moralniejsze; ale mężczyźni mówią, że ponieważ kobiety mają za dużo uczucia, to dlatego nie chca, żeby kobiety wypowiadały swój sąd! Czy to jest sens? Czy to jest logika? ${ }^{32}$

Przemyślność kobieca, dostrzegana w poczynaniach parlamentarzystek, miała się okazać użyteczna podczas kryzysu gospodarczego lat 19291933, gdy zaradność, zapobiegliwość, umiejętność racjonalnego kierowania budżetem własnego domu rodzinnego nabierały znaczenia w makroskali. Stawała się przedmiotem uogólnień na temat możliwości jej spożytkowania pro publico bono mieszkańców Rzeczypospolitej Polskiej.

Argumentacja na rzecz upełnomocnienia kobiet do roli osób, które potrafiły uporządkować sytuację w państwie, towarzyszyła poczynaniom środowisk kobiecych wspierających obóz sanacji politycznej. Wskazywano na „cechy niewieście” użyteczne przy niwelacji „bezładu sejmowego” w domyśle spowodowanego przez polityków-mężczyzn z obozu opozycyj-

29 „O czym wiedzieć i w obronie czego musza stanąc kobiety?”, Głos Kobiety, nr 5, 1931, 2.

30 Cecylia Walewska, „O równe prawa. Julia Dickstein-Wieleżyńska”, Kobieta Współczesna, nr 10, 1927, 3.

31 Nina, „Pani mody”, Pani, nr 2, 3.02.1925, 49; Jerzy Bratkowski, „Rola kobiety w życiu gospodarczym państwa”, Polka, nr 8, 1926, 1.

32 Justyna Budzińska-Tylicka, „Prawa i obowiązki kobiet”, Głos Kobiet, nr 3, 1928, 4. 
nego do rządów pomajowych ${ }^{33}$. Jednak publicystyka prasowa - szczególnie sterowana przez redakcje pism umiarkowanych - nie ogłaszała walki z mężczyznami, a niekiedy wręcz niwelowała ryzyko ujawniania się antagonizmu płci. Szczególnie w czasopismach skierowanych do mieszkanek wsi widoczna była taktyka umiarkowania w kwestii dalszych działań w interesie kobiet. W tekście z 1939 r. zwrócono uwage na konieczność dawkowania zabiegów o egalitaryzm płciowy. $Z$ pietyzmem przypominano, że wola kobiety, by współrządzić przestrzenia publiczna, nie stanowiła zagrożenia dla porządku płci, ponieważ

chcemy w Polsce współgospodarzyć, nie $z$ chęci panowania nad bratem, bo ta zawsze była nam obca, ale w imię sprawiedliwości i równości społecznej. I o to słuszne prawo walczyć będziemy, aż do zwycięstwa ${ }^{34}$.

Tego typu konstatacja była wielokrotnie i w różnych wersjach stosowana, gdy przywoływano obowiazkowość, odpowiedzialność, staranność, sumienność obywatelek. Miała zapewne uspokajać opinię publiczna, by nie lękała się, że emancypacyjne sukcesy będa prowadziły do przywilejów kobiet, do nieuzasadnionego nobilitowania ze względu na płeć czy do efektywnego konkurowania z mężczyznami. Kody płci pozwalały na nakreślenie wizerunku parlamentarzystek, które z powodów natury charakterologicznej, przynależnych kobietom, mogły uszlachetnić życie polityczne w Polsce. Stęślicka przekonywała, że

kobieta bowiem dopiero wówczas będzie należycie spełniała swe zadania w narodzie, jeśli przez wykształcenie ogólne zdoła pogłębić swój umysł i duszę, nie zatracając nic $z$ swej odrębności kobiecej; wnosząc zaś cały zapas szlachetnej uczuciowości serca kobiecego w życie narodu; łagodzić będzie nadmierne tarcia i przeciwieństwa i podnosić poziom moralny ogółu ${ }^{35}$.

Dążeniom do pokazania, że kobiety, mając możliwość decydowania o sprawach publicznych, osiagały rezultaty nie gorsze od mężczyzn, towarzyszyło nieodłączne prezentowanie spraw osobistych poszczególnych parlamentarzystek. Przynajmniej w stosunku do niektórych pań publicystyka prasowa konsekwentnie zmierzała do przedstawiania ich

\footnotetext{
${ }^{33}$ Herminia Naglerowa, „Polityczne i społeczne postulaty kobiet”, Bluszcz, nr 45, 1930, 3.

34 „Nasza droga”, Kobieta Wiejska, nr 1, 1939, 1.

35 Halina Stęślicka, „Ze zjazdu”, 3.
} 
w rolach społecznie oczekiwanych, a więc przez pryzmat małżeństwa i macierzyństwa. Znamienny przykład stanowiła sylwetka Zofii Moraczewskiej opisana w przedwyborczym tekście $z$ kampanii 1930 r. Znalazły się w nim naprzemienne informacje o jej pracy politycznej oraz o życiu osobistym (małżeństwo z Jędrzejem w 1896 r.), o tragedii rodzinnej (śmierć syna podczas obrony Warszawy w 1920 r.) ${ }^{36}$. Parlamentarzystki, będące zarazem publicystkami, świadomie sięgały do ugruntowania własnej pozycji wskutek spożytkowania wiedzy o ich powinności wobec rodziny. Widać było wiedzę o komunikacyjnej wartości mitu matki Polki. Powielały schemat, że wartość kobiety była mierzona przez pryzmat rodziny. Chadecka posłanka jednoznacznie tłumaczyła czytelniczkom:

nie ulega najmniejszej watpliwości, że aby spełnić swe zadanie należycie, musi kobieta poświęcić rodzinie dużo czasu i zabiegów, jest $z$ rodzina swa zwiazana prawie zupełnie, o ile wszystkie obowiazki pragnie wypełnić sumiennie ${ }^{37}$.

Zrozumiałe zatem było, że nie tylko Moraczewska, znana i ceniona posłanka, lecz także inne parlamentarzystki miały prasowy obraz wypełniony odniesieniami do ich spraw prywatnych. Nawet gdy nie posiadały własnych dzieci, pokazywano je jako doświadczone nauczycielki czy oddane opiekunki bratanic, siostrzenic i innych młodocianych członków rodziny. Potwierdzały umiejętności wychowania młodego pokolenia i wypełniania obowiązków wobec ojczyzny.

We wzorcowym wizerunku znajdowały się efekty idealizacji kobiet cnotliwych, wstrzemięźliwych, prostolinijnych. Powoływano się na dążność części parlamentarzystek do tego, by „życie towarzyskie i publiczne jak najwięcej było skromne i czyste, wiodące do poszanowania życia rodzinnego i kobiety"38. Oceniając życie polityczne w Polsce, zakładano,

\footnotetext{
36 „Nasze kandydatki”, Jedynka. Organ Komitetu Wyborczego Organizacji Kobiecych, nr 2, 1930, 2. O życiu prywatnym Z. Moraczewskiej zob. Ilona Florczak, „Socjalistka na prowincji - społeczna i polityczna działalność Zofii Moraczewskiej w Galicji (do 1914 roku)", w: Jolanta Kamińska-Kwak, Szczepan Kozak, Dariusz Opaliński (red.), Kobieta w Galicji. Nowoczesność i tradycja, (Rzeszów : Wydawnictwo Uniwersytetu Rzeszowskiego, 2016), 296-310.

37 Halina Stęślicka, „Ze zjazdu”, 3. Podkreślanie znaczenia rodziny dla kobiet nie ograniczało krytyki tzw. ustawy celibatowej dla nauczycielek, „Dziwne uchwały Sejmu Śląskiego, Kobieta Współczesna, nr 7, 1927, 14.

38 „Wiadomości Zarzadu Sekretariatu Generalnego”, Gazeta dla Kobiet, nr 1, 1923, 1; Z.Z., „W zjednoczeniu siła i podpora”, Ziemianka Polska, nr 23, 1930, 6-8.
} 
że obecność parlamentarzystek w działaniach legislacyjnych łagodziła napięcia, chroniła nastrój sejmowy przed radykalizacja. W ten sposób prezentowany w prasie wzorzec posłanki czy senatorki był zarazem ideałem kobiety oraz ideałem obywatelki wrażliwej na sprawy społeczne. Towarzyszyła mu wspólnota pojęć typowych dla aktywistek kobiecych, jak (samo)kształcenie, edukowanie, wychowywanie, upowszechnianie prospołecznych postaw, ale też przyuczanie do zarządzania nie tylko w sferze prywatnej (gospodarstwo domowe), lecz także w sferze publicznej (polityka, ekonomika, kultura).

\section{Wzorzec polityczności i obywatelskości - kody władzy}

Stereotypy kobiecości właściwe dla przestrzeni prywatnej były wzbogacane o cechy pożąane w życiu politycznym. W przekazie prasowym zwracano uwage na uzasadnienie życiowych wyborów parlamentarzystek decydujacych się na wejście w przestrzeń dotychczas zarezerwowaną dla mężczyzn. Jednocześnie w sferze zainteresowań zespołów redakcyjnych prasy dla kobiet pozostawała kwestia predyspozycji osobowościowych posłanek i senatorek. Przy kreowaniu wizerunków parlamentarzystek używane były słowa: energia, entuzjazm, ruchliwość, poświęcenie dla sprawy, talent organizatorski, zdolności oratorskie. Nadmieniano o przemyślności kobiecej, użytecznej przy prowadzeniu skutecznej działalności na forum Sejmu i Senatu oraz w społeczeństwie. Powstawały wzorce pracy dla dobra ogółu skorelowanej ze sfera prywatna parlamentarzystek ${ }^{39}$. Były one zwielokrotnione, w nich powielany był schemat cech wspólnych niezależnie od przynależności politycznej (partyjnej, klubowej) uczestniczek prac legislacyjnych. Wspomniano już wcześniej, że parlamentarzystki, będące też publicystkami, informowały czytelniczki o zasługach koleżanek $z$ ław poselskich. Podawały do wiadomości publicznej konkretne dane wraz ze wzmiankami o solidarności

\footnotetext{
39 Pojawiały się uogólnienia dotyczace pogodzenia życia osobistego kobiet $\mathrm{z}$ ich aktywnościa na rzecz spraw społecznych. Relacjonując spotkanie posłanki Bronisławy Szymkowiakówny, zwracano uwage, że „w wykładzie p. Szymkowiakówny spotkały zebrane ogromnie dużo szczerej i serdecznej zachęty do pracy społecznej, od której usuwać nie powinna się żadna kobieta polska. ... Rozsądna kobieta potrafi bez szwanku dla domu i rodziny poświęcić część swego czasu dla zadań społecznych. Nie można dzisiaj już zasklepiać się w ciasnym swoim środowisku domowym, trzeba poznać społeczeństwo, ustawy, państwo, jego choroby i braki”, „Zjazd Delegowanych Zwiazku Kobiet Pracujących”, Gazeta dla Kobiet, nr 7 (zwiazkowy), 1926, 2.
} 
ponad podziałami światopoglądowymi w kwestiach dotyczących kobiet, dzieci, rodziny. Sytuacja parlamentarzystek była szczególna, ponieważ występowało podwójne uzależnienie: płciowe i polityczne. Oczekiwanie efektów lojalności wobec „siostrzeństwa” wymagało umiejętności pogodzenia dążeń do realizacji interesów środowisk kobiecych z oczekiwaniami władz klubów sejmowych czy senackich. Na dodatek musiały zdawać test relewancji w parlamencie, by okazać skuteczność pracy na rzecz praw płci. Kwestia walki $z$ dyskryminacja kobiet skłaniała do ustalenia trzech typów strategii politycznych stosowanych w toku pracy politycznej w postaci: (1) koncentracji horyzontalnej, gdy parlamentarzystki podejmowały współpracę w obszarze wspólnoty aksjologicznej, (2) koncentracji wertykalnej podczas tworzenia okresowej wspólnoty działań na rzecz konkretnej sprawy, (3) koncentracji konglomeracyjnej polegającej na dobieraniu sojuszniczek spoza przestrzeni parlamentarnej.

Prasa dla kobiet posiłkowała się informacjami o środkach ekspresji parlamentarzystek, upowszechniajacych wiedzę na temat mechanizmów pracy w instytucjach przedstawicielskich. Posłanki i senatorki na ogół wykorzystywały sprawdzone środki oddziaływania na odbiorczynie w postaci odczytów, prelekcji, wykładów, rzadko sięgając do innych form bezpośredniego przekazu treści ideowych. O zaangażowaniu posłanek Haliny Stęślickiej i Janiny Omańkowskiej w organizację ruchu odczytowego informowano w każdym niemal numerze pisma "Głos Polek”. Podawano nazwy miejscowości i adresy lokali, w których odbywały się poselskie spotkania. Ich przebieg potwierdzał komunikacyjne predyspozycje parlamentarzy$\mathrm{stek}^{40}$. Przekaz prasowy pozwalał na konstatowanie prawidłowości interpretacji rzeczywistości społecznej przez posłanki, konfrontowania opinii $z$ innymi ocenami i komentarzami, odczuwania empatii w interakcjach z lokalną ludnością. Skądinąd dawał możliwość sformułowania pochwalnych uwag o parlamentarzystkach obdarzonych konkretnymi uzdolnieniami komunikacyjnymi. Na temat kwalifikacji senatorki Zofii Daszyńskiej-Golińskiej publicystka tygodnika „Kobieta Współczesna” napisała:

Między godziny robocze, którymi wypełniony jest dzień jej po brzegi, umie zawsze wcisnąć jakąs jedną, żeby przemówić bądź na cel dobroczynny, bądź w sprawie oświatowo-społecznej. Obdarzona darem słowa, logiką ujmowania jądra zagadnień i talentem popularyzatorskim,

40 „Kalendarzyk zebran”, Głos Polek. Organ Zwiazku Towarzystw Polek, nr 17, 1923, 4. 
umie być zrozumiana zarówno przez inteligentów, jak i analfabetów. Stąd wielka jej wziętość jako prelegentki ${ }^{41}$.

Uwage kobiecej publicystyki prasowej przez cały niemal czas istnienia Polski międzywojennej skupiała sprawa przeciwdziałania alkoholizmowi. Nadano jej range zagadnienia decydujacego o losach narodu i państwa, dlatego kwestia walki parlamentarzystek o ustawowe uregulowanie wyrobu i sprzedaży napojów spirytusowych stanowiła ośrodek nieustannego zainteresowania. Argumentacja zawierała priorytetowe ujęcie dwóch kwestii: po pierwsze, zwracano uwage na zagrożenia Polski wskutek braku kompleksowej ochrony przed patologia społeczna, po drugie, podkreślano wystapienie objawów ponadpartyjnej wspólnoty celów parlamentarzystek, ponieważ

tu chodzi o coś ważniejszego, niż przemijające programy stronnictw - tu chodzi o odwrócenie wspólnego wroga szczęścia i spokoju rodzinnego, regeneratora rasy. Jakże łatwo porozumieć się na tym terenie, jak łatwo utworzyć wspólny front przeciw nikczemnej spekulacji, podającej truciznę słabym, znałogowanym głowom ${ }^{42}$.

Panowała wspólnota zgody przy formułowaniu pochwał pod adresem Marii Moczydłowskiej, posłanki na Sejm Ustawodawczy, autorki planu reglamentacji sprzedaży napojów alkoholowych. Wzmiankowano, że projekt jej autorstwa stał się wzorem dla wielu państw Europy. Mimo pisania o łatwości, z jaka powstał sojusz parlamentarzystek, publicystyka ukierunkowana na kobiety podkreślała znaczenie „energicznej akcji” promowania lex Moczydłowska przez Balicka, Kosmowska, Moraczewska, które w atmosferze bierności, a nawet przy niechęci ogółu (męskiego) Sejmu, „dzielnie popierały wnioskodawczynię"43.

Wykreowany wizerunek zawierał komponenty pozytywnej działalności osób, którym zależało na poprawie kondycji duchowej i material-

\footnotetext{
41 Cecylia Walewska, „O równe prawa. Dr Zofia Daszyńska-Golińska”, Kobieta Współczesna, nr 5, 1927, 5.

42 „W walce $\mathrm{z}$ alkoholizmem”, Kobieta Wspótczesna, nr 1, 1927, 16; zob. Mariola Kondracka, Posłanki, 178-180.

43 Alina Trusiewiczowa, „Kobieta w parlamencie polskim”, w: Almanach Spraw Kobiecych, (Warszawa : Wydział Prasowy ZPOK), 1933, VIII; „Abstynencja jako środek walki z alkoholem", Pod Znakiem Marii, nr 5, 1928, 101-103; Kobieta w Sejmie. Działalność posłanek Narodowej Organizacji Kobiet: zarys sprawozdania za lata 1919-1927, (Warszawa : Narodowa Organizacja Kobiet, 1928), 20.
} 
nej społeczeństwa. Ponadto mieścił w sobie odniesienia do skuteczności poczynań kobiety zdeterminowanej okolicznościami życiowymi, znanymi $z$ obserwacji oraz $z$ doświadczeń własnych. Problem ogólnospołeczny dawał sposobność do pokazania objawów kobiecej życzliwości i sympatii, co znajdowało odzwierciedlenie w opisach klimatu spotkań posłanek:

Stosunek tych wszystkich pań do siebie w najwyższym stopniu kurtuazyjny, życzliwy, koleżeński. Gdy chodzi o walkę z klęskami społeczny$\mathrm{mi}$, nie istnieją dla nich różnice polityczne, przynależności partyjne ${ }^{44}$.

Redakcja tygodnika „Kobieta Współczesna” idealizowała sytuację, ale też dawała jednoznaczny przekaz mobilizujacy do tworzenia przeciwwagi dla przejawów polityki zmaskulinizowanej, pełnej negatywnych emocji i czynów. Niemal wszystkie periodyki ukierunkowane na kobiety w kolejnych latach obserwacji życia parlamentarnego powracały do sytuacji w Sejmie Ustawodawczym i triumfalnie przywoływały sukces parlamentarzystek, dając dowód możliwości wykreowania wzorca zwielokrotnionego i uniwersalizowanego na użytek pedagogiki społecznej versus narodowej czy obywatelskiej.

Parlamentarzystki $z$ oczywistych powodów tworzyły wyłom w systemie patriarchalnych stosunków społecznych. Były ex definitione dowodem sukcesów kobiecych przez to, że osiagnęły status członkiń instytucji przedstawicielstwa narodowego. Publicystyka prasowa dla kobiet uczestniczyła jednak w procesie utrwalania stereotypu posłanki czy senatorki zajmującej się zagadnieniami o znaczeniu społecznym i o randze ponadczasowej, ale zdeterminowanej przez płeć. Niejako powielano schematyzm klasyfikowania prac parlamentarzystek w kontekście tematów identyfikowanych z kobiecościa, jak macierzyństwo, opieka nad dziećmi, ochrona przed wykluczeniem społecznym. Uwaga czytelniczek miała się skupić na sejmowych „bojownicach” walczacych o zabezpieczenie rodziny przed destabilizacja (rozwody), przed upadkiem obyczajów i demoralizacja (pornografia, prostytucja). Kreowano wzorcowy wizerunek parlamentarzystki zaangażowanej w przeprowadzenie procedury legislacyjnej przy zmianie przepisów prawa cywilnego zwiazanych z prawami kobiet, uchwalenie ustawy dotyczacej zwalczania handlu kobietami i dziećmi czy szeregu ustaw o opiece społecznej. Liczne były wzmianki o planach złożenia projektów związanych $z$ systemem oświaty i z realiza-

44 „W walce $\mathrm{z}$ alkoholizmem”, Kobieta Współczesna, nr 1, 1927, 16. 
cja konstytucyjnych praw do pobierania nauki w systemie szkolnictwa powszechnego. Tym samym umacniano wizerunek kobiety w polityce aktywnej, ale ograniczonej do kręgu zagadnień „miękkich”, jak oświata, kultura, sprawy socjalno-bytowe. Natomiast zagadnienia „twarde”, jak polityka zagraniczna czy obronność państwa, mimo że znajdowały się w agendzie zainteresowań parlamentarzystek (przykładowo w sejmowej komisji spraw zagranicznych intensywnie pracowały Maria Holder-Eggerowa i Irena Kosmowska), pozostawały poza pogłębionym przekazem komunikacyjnym.

Przy ukazywaniu zagadnień „miękkich” uwidoczniła się dążność do uwypuklenia specjalizacji poszczególnych pań na forum parlamentu, nawet wówczas gdy nie uzyskały tak spektakularnych osiagnięć jak w wypadku ustawy antyalkoholowej. Nadmieniano o zaangażowaniu się Doroty Kłuszyńskiej w krytykę projektu rządowego z 23 stycznia 1928 r. w sprawie wykluczenia kobiet od udziału w sadach przysięgłych, przypominając, że „w całej Konstytucji nie ma takiego paragrafu - żeby tylko mężczyźni posiadali jakie bądź inne prawa jak kobiety" ${ }^{45}$. Sporo miejsca publicystyka prasowa poświęcała Daszyńskiej-Golińskiej przygotowującej projekty ustawy o pracy młodocianych i kobiet, a także Moraczewskiej, która żądała likwidacji absurdów prawnych, jak niedopuszczenie kobiet do stowarzyszeń politycznych (art. 36 ustawy austriackiej), a ponadto domagała się ustawowego zabezpieczenia materialnego wdów i sierot wojennych. Pisano też o aktywności posłanek Jadwigi Dziubińskiej i Ireny Kosmowskiej zabiegających o rozwój żeńskiego szkolnictwa rolniczego. W każdej kwestii poruszanej przez parlamentarzystki, jak sprawa regulacji statusu żeńskiej służby domowej (Wanda Ładzina), inspekcji pracy kobiet (Zofia Praussowa), ochrony przed demoralizacja (Maria Holder-Eggerowa) i przed komunizmem (Ewelina Pepłowska) oraz przeciwdziałania nadużyciom ze strony urzędów administracji publicznej (Franciszka Wilczkowiakowa), przypominano, że znalazły się w sferze zainteresowań publicznych dzięki „żywej inicjatywie” posłanek ${ }^{46}$. Sprawy

\footnotetext{
45 Justyna Budzińska-Tylicka, „Prawa”, 4.

46 E.W., "Stanowisko kobiety w świetle obowiazującego na ziemiach wschodnich prawa”, Kobieta Obywatelka, dodatek do Kuriera Wileńskiego, nr 7, 1930, 4; Helena Ceysingerówna, „Mężatki”, Kobieta Współczesna, nr 9, 1927, 2-3; Sylwia Bujak-Boguska, „Ograniczenie praw kobiet w ustawodawstwie prywatno-prawnym”, Kobieta Współczesna, nr 44, 1930, 5; N.J., „Wanda Ładzina. (Sylwetka działaczki kulturalno-społecznej)”, Bluszcz, nr 22, 1930, 3-4; „Kobiety a polityka. Referat pos. Eweliny Pepłowskiej wygłoszony na wielkim zebraniu NOK w Wilnie", Hasło Polki, nr 4, 1934, 1; zob. Natalia Gorzkiewicz,
} 
obywatelek Rzeczypospolitej Polskiej były diagnozowane na tle międzynarodowym. Specjalny wywiad z senatorka Szebeko przeprowadziła redakcja tygodnika „Kobieta Współczesna” celem upowszechnienia informacji o Międzynarodowej Radzie Kobiet, jej strukturze i kompetencjach ${ }^{47}$. Cechą wysoko cenioną było uzdolnienie krasomówcze parlamentarzystek. Wzmiankowano o przemówieniach Zofii Sokolnickiej, która „z zapałem i niezwykłą energia”" wyrażała troskę o stan szkolnictwa wyższego, o państwowy system stypendialny, o odpowiednie uposażenie kadry naukowej i dydaktycznej. Obszernie wypowiadała się na temat potrzeby podniesienia poziomu oświaty na Pomorzu w kierunku odwrócenia skutków germanizowania dzielnicy. Nadmieniała o znaczeniu szkolnictwa żeńskiego kształcącego „zastępy bojownic o Polskę"48.

Wzmiankowana wyżej kwestia solidarnej pracy parlamentarzystek oraz gotowości publicystek do idealizowania relacji między nimi nie odzwierciedlała wielu komponentów wizerunku medialnego złożonego z zagadnień światopoglądowych. W wielu kwestiach dotyczących nierozerwalności sakramentu małżeństwa czy świadomego planowania rodziny w kontekście ochrony życia ludzkiego formułowane były odrębne opinie, które w prasie dla kobiet przybierały postać sporów o podłożu konfesyjnym i skutkowały negowaniem działań parlamentarzystek z przeciwnego obozu $^{49}$. Ponadto załamanie wizerunku solidarnych aktywistek sejmowych, lojalnych wobec koleżanek $z$ innych klubów, nastąpiło wskutek narastania rywalizacji o mandaty do instytucji przedstawicielskich. Do modyfikacji doszło w okresie kształtowania opozycji antysanacyjnej, kiedy skończył się czas obowiazywania konwencji pisania o rywalkach jako „czcigodnych i zasłużonych”. W części periodyków przeznaczonych dla

„Czasopismo "Bluszcz" a aktywność zawodowa kobiet w latach 1926-1928", w: Radosław Sioma (red.), Kobiece dwudziestolecie 1918-1939, (Toruń : Wydawnictwo Naukowe Uniwersytetu Mikołaja Kopernika, 2018), 71-85.

47 „Przed wyjazdem do Genewy. Wywiad z p. senatorka Józefą Szebekówna”, Kobieta Wspótczesna, nr 6, 1927, 5-6; N.K., „Międzynarodowe zjazdy kobiet. Zjazd Rady Międzynarodowej Kobiet w Genewie”, Kobieta Współczesna, nr 16, 1927, 17.

48 „Ze wszystkich jej przemówień tchnie głęboka wiara w potęgę nauki i wiedzy, szczera, wzruszająca troska o kulturę polska, o byt akademika, uczonego i badacza", Alina Trusiewiczowa, Kobieta, VII.

49 Negatywnie o zjawisku „zamieszania pojęć moralnych, filozoficznych, religijnych” wypowiadały się publicystki czasopism konserwatywnych, katolickich i narodowych, zob. „Kodeks Karny”, Ziemianka Polska, nr 21, 1930, 10-12; Por. Dobrochna Kałwa, „Głosy kobiet w sprawie planowania rodziny w świetle prasy z lat 1929-1932”, w: Anna Żarnowska, Andrzej Szwarc (red.), Kobieta i kultura życia codziennego. Wiek XIX i XX, (Warszawa : Wydawnictwo DiG, 1997), 123-132. 
kobiet uwidoczniły się skutki zmian zachodzacych w życiu politycznym i powstania bloków wyborczych o jednoznacznie sformułowanym programie partyjnym.

Przed wyborami w 1930 r. dały znać o sobie procesy korekty reguł kreślenia portretów parlamentarzystek. Bezwzględna walka między obozem rządowym a opozycja antysanacyjna prowadziła do pojawienia się głosów krytycznych wobec kobiet, które znalazły się po drugiej stronie politycznej. Władysława Weychert-Szymanowska, znana animatorka ruchu kobiecego, socjalistka, na łamach pisma opozycyjnego „Głos Ludu" w tekście skierowanym do wyborczyń dementowała informację, że kandydatki do parlamentu $z$ list Bezpartyjnego Bloku Wspierania Rządu (BBWR) reprezentowały socjalistyczny program. Przekonywała, że „rozbijacze $z$ Bebeesu $z$ Jaworowskim i Praussową na czele chwalą się, że maja listę wyłącznie socjalistyczną i z nikim się nie łączą" ${ }^{50}$. Odpowiedzią były informacje podawane w tygodniku „Bluszcz” oraz w organach prasowych ZPOK, jak „Praca Obywatelska” i „Prosta Droga”, zawierające uwagę, że dzięki listom BBWR kobiety „stworzyły własny, samodzielny komitet” i nie zadawalały się „agitacja pod przewodnictwem męskim” ${ }^{1}$. Zmiana tonu politycznego i kryzys zaufania do obozu rzadowego sprawiły, że w styczniu 1931 r. w tygodniku „Kobieta Współczesna” opublikowano list otwarty do parlamentarzystek BBWR w sprawie brzeskiej. Redakcja podkreślała apolityczny charakter swojego pisma, bez nadawania mu partyjnego wymiaru, a druk listu tłumaczyła „najprostszymi uczuciami ludzkimi" przeciw łamaniu zasad etyki. Odnosząc się do kwestii obecności kobiet w polityce, stwierdzono że „kobiety nie mogą pozostać obojętne wobec faktów rujnujacych od podstaw pracę wychowawczą i kulturalną, odbierających jej sens i wartość"52.

Kształtowanie i upowszechnianie wzorca parlamentarzystek przybierało postać procesów afirmacji, czasem deprecjacji zachodzacych $\mathrm{w}$ trakcie podporządkowania interesów kobiecych pożytkom polityki identyfikowanej $z$ wybranym katalogiem wartości: chrześcijańsko-de-

\footnotetext{
50 Władysława Weychertowa-Szymanowska, „Głosujemy na listę nr 7”, Głos Ludu, listopad 1930, 3.

51 Natalia Jastrzębska, „Kobiety w akcji wyborczej”, Bluszcz, nr 43, 1930, 2; Helena Ceysingerówna, „Zwiazek Pracy Obywatelskiej Kobiet”, w: Katalog Wystawy „Świat Kobiety”, (Warszawa : ZPOK, 1939), 10.

52 „Do posłanek BBWR. List otwarty”, Kobieta Współczesna, nr 1, 1931, 14; Mirosława Dołęgowska-Wysocka, „Tygodnik "Kobieta Współczesna” 1927-1934”, Kwartalnik Historii Prasy Polskiej, t. 21, nr 3-4, 1982, 65; Joanna Dufrat, W służbie, 17-18.
} 
mokratycznych, katolickich, konserwatywnych, liberalnych, narodowodemokratycznych, socjalistycznych. $Z$ tego powodu kreowany w prasie dla kobiet wizerunek nie był monolitem, choć mieścił w sobie uniwersalia podbudowane wartościami humanistycznymi na ogół identyfikowanymi $z$ wrażliwością kobieca, z pozyskiwaniem wiedzy o rzeczywistości społecznej, $z$ określaniem kwalifikacji niezbędnych do prawidłowego wykonywania służby publicznej.

\section{Zakończenie}

Procesowi kreowania wzorcowego wizerunku parlamentarzystek towarzyszyło przekonanie o istnieniu interakcji między kobietami, o możliwościach sterowania nimi przez narzędzia i techniki właściwe mediom masowym, ponadto o konieczności integrowania środowisk kobiecych wokół konkretnego systemu wartości. Wypełniano reguły female communication, dając konkretne stylizacje instytucjonalne (prasa dla kobiet, redaktorki, publicystki) i osobowościowe („bojownice” o interesy kobiet). Przybliżanie czytelniczkom sylwetek posłanek i senatorek w perspektywie kobiecości (kody płci) oraz fachowości politycznej (kody władzy) dawało konkretne korzyści w postaci kształtowania agendy wspólnych tematów, wzmacniania poczucia przynależności do grupy, ustalania reguł współpracy, pozyskiwania aprobaty, zdobywania prestiżu w warunkach konkurencji na rynku komunikacji społecznej. Do spełnienia posłannictwa prasowego niezbędne były autorytety ze świata kobiecego celem pokazania stanu idealnego, w którym kobieta może osiagnąć indywidualny sukces, dający szansę na wzmocnienie się wspólnoty. Względnie szeroka możliwość prezentowania obrazów świata $z$ perspektywy pracy parlamentarnej tworzyła okazję do konfrontowania zróżnicowanych ideowo projektów emancypacyjnych.

Parlamentarzystki jako obiekty zainteresowań prasowych należały do świata zaufania społecznego, cechowała je powaga wynikająca z pełnionych ról społecznych, piastowanych funkcji, statusu intelektualnego, kulturalnego, finansowego. Aktualność i zrozumiałość przekazu medialnego, ale też wielogłosowość wypowiedzi politycznych dały podwaliny poznania prasowych przestrzeni kobiecej podmiotowości oraz kobiecej tożsamości. 


\section{Bibliografia}

\section{Źródła:}

„Abstynencja jako środek walki z alkoholem”, Pod Znakiem Marii, nr 5, 1928. „Do posłanek BBWR. List otwarty”, Kobieta Współczesna, nr 1, 1931. „Dziwne uchwały Sejmu Śląskiego, Kobieta Wspótczesna, nr 7, 1927. „Jubileusz Niewiast Katolickich w Jabłonkowie”, Niewiasta Katolicka, nr 7, 1931.

„Kalendarzyk zebrañ”, Głos Polek. Organ Zwiazku Towarzystw Polek, nr 17, 1923.

„Kobiety a polityka. Referat pos. Eweliny Pepłowskiej wygłoszony na wielkim zebraniu NOK w Wilnie", Hasło Polki, nr 4, 1934.

„Kodeks Karny”, Ziemianka Polska, nr 21, 1930.

„Kronika działalności kobiecej”, Bluszcz, nr 51, 1918.

„Nasi kandydaci”, Głos Wielkopolanek, nr 42, 1922.

„Nasza droga”, Kobieta Wiejska, nr 1, 1939.

„Nasze kandydatki”, Jedynka. Organ Komitetu Wyborczego Organizacji Kobiecych, $\mathrm{nr}$ 2, 1930.

„Nowe posłanki i senatorki”, Kobieta Współczesna, nr 52, 1930.

„O czym wiedzieć i w obronie czego muszą stanać kobiety?”, Głos Kobiety, nr 5, 1931.

„O powrót kobiety-matki do ogniska domowego", Gazeta dla Kobiet, nr 6, 1933.

„O równe prawa dla kobiet”, Gazeta dla Kobiet, nr 26, 1918.

„Przed wyjazdem do Genewy. Wywiad z p. senatorką Józefą Szebekówną, Kobieta Współczesna, nr 6, 1927.

„Rozrzućmy we wrześniu "Młodą Polkę» - tysiącami”, Młoda Polka, nr 7, 1939.

„Rozważania przedwyborcze”, Gazeta dla Kobiet, nr 2, 1928.

„Ruch kobiecy”, Gazeta dla Kobiet, nr 4, 1928.

„Sprawozdanie z 24 Zjazdu Delegowanych Stowarzyszeń Związku Kobiet

Pracujących w dniu 1 czerwca 1930 r. w Poznaniu", Gazeta dla Kobiet, nr 10, 1930.

„Stanowisko kobiet w różnych narodach”, Niewiasta Katolicka, nr 5, 1931. „W walce z alkoholizmem”, Kobieta Wspótczesna, nr 1, 1927. 
„Wiadomości Zarzadu Sekretariatu Generalnego”, Gazeta dla Kobiet, nr 1, 1923.

„Wybory”, Gazeta dla Kobiet, nr 9, 1935.

„Zjazd Delegowanych Zwiazku Kobiet Pracujących”, Gazeta dla Kobiet, nr 7 (nr zwiazkowy), 1926.

Appenszlakowa, Paulina. „Cel w życiu (Kilka słów o "ideale zamażpójścia»)", Ewa, nr 11, 1928.

Bratkowski, Jerzy. „Rola kobiety w życiu gospodarczym państwa”, Polka, nr 8, 1926.

Budzińska-Tylicka, Justyna. „Prawa i obowiąki kobiet”, Głos Kobiet, nr 3, 1928.

Bujak-Boguska, Sylwia. „Ograniczenie praw kobiet w ustawodawstwie prywatno-prawnym", Kobieta Współczesna, nr 44, 1930.

Bujak-Boguska, Sylwia. Na straży praw kobiety. Pamiętnik Klubu Politycznego Kobiet Postępowych 1919-1930, (Warszawa : bw, 1930).

Ceysingerówna, Helena. „Mężatki”, Kobieta Współczesna, nr 9, 1927.

Ceysingerówna, Helena. „O poczuciu obowiązu obywatelskiego. Wywiad z senatorką dr Zofią Daszyńską-Golińską", Kobieta Wspótczesna, nr 25, 1928.

Ceysingerówna, Helena. „Zwiazek Pracy Obywatelskiej Kobiet”, w: Katalog Wystawy „Świat Kobiety”, (Warszawa : ZPOK, 1939), 7-12.

Daszyńska-Golińska, Zofia. „Tereny doświadczalne parlamentarnej pracy kobiet", Na Posterunku, nr 21, 1917.

E.W. „Stanowisko kobiety w świetle obowiazującego na ziemiach wschodnich prawa”, Kobieta Obywatelka, dodatek do Kuriera Wileńskiego, nr 7, 1930.

Jastrzębska, Natalia. „Kobiety w akcji wyborczej”, Bluszcz, nr 43, 1930.

Kłuszyńska, Dorota. „Udział kobiet w zwycięstwie wyborczym PPS”, Głos Kobiet, nr 4, 1928.

Kłuszyńska, Dorota. „Wyborczynie, w waszych rękach zwycięstwo”, Głos Kobiet, nr wyborczy, 1928.

Kobieta w Sejmie. Działalność posłanek Narodowej Organizacji Kobiet: zarys sprawozdania za lata 1919-1927, (Warszawa : Narodowa Organizacja Kobiet, 1928).

Milewska, Olga. „Pójdź - jesteś potrzebna”, Głos Wielkopolanek, 1922, nr 39. N.J. „Wanda Ładzina. (Sylwetka działaczki kulturalno-społecznej)”, Bluszcz, nr 22, 1930. 
N.K. „Międzynarodowe zjazdy kobiet. Zjazd Rady Międzynarodowej Kobiet w Genewie”, Kobieta Współczesna, nr 16, 1927.

Naglerowa, Herminia. „Polityczne i społeczne postulaty kobiet”, Bluszcz, nr 45, 1930.

Nina. „Pani mody”, Pani, nr 2, 1925.

Podhorska-Okołów, Stefania. „Przed nową próba sił”, Bluszcz, nr 1, 1928.

Stęślicka, Halina. „Ze zjazdu Zwiazku Kobiet Prac. W Gnieźnie w 1924 roku

(wyjatek z mowy poselskiej)", Gazeta dla Kobiet, nr 7, 1924.

Tatarówna, Stefania. „Na przełomie”, Głos Wielkopolanek, nr 5, 1924.

Trusiewiczowa, Alina. „Kobieta w parlamencie polskim”, w: Almanach Spraw

Kobiecych, (Warszawa : Wydział Prasowy ZPOK, 1933), VI-XIII.

Tuchołkowa, Stefania. „Udział kobiety w polityce”, Głos Wielkopolanek, nr 44, 1922.

Walewska, Cecylia. „O równe prawa”, Kobieta Wspótczesna, nr 18, 1927.

Walewska, Cecylia. „O równe prawa. Dr Zofia Daszyńska-Golińska”, Kobieta Wspótczesna, nr 5, 1927.

Walewska, Cecylia. „O równe prawa. Julia Dickstein-Wieleżyńska”, Kobieta Współczesna, nr 10, 1927.

Weychertowa-Szymanowska, Władysława. „Głosujemy na listę nr 7”, Głos Ludu, listopad 1930.

Własnymi Siłami. Miesięcznik dla kobiety katolickiej, nr 1, 1939.

Z.Z. „W zjednoczeniu siła i podpora”, Ziemianka Polska, nr 23, 1930.

Zaleska, Zofia. „Obozownictwo jako sport”, Bluszcz, nr 34, 1928.

Zaleska, Zofia. Czasopisma kobiece $w$ Polsce. (Materiaty do historii czasopism). Rok 1818-1937, (Warszawa : Wyższa Szkoła Dziennikarska, 1938). Zdanowska, Aniela. „O zdrowiu”, Przodownica, nr 2, 1931.

Żebrowska, Wanda. „Do Czytelniczek”, Przodownica, nr 15, 1931.

Żurawska, Felicja. „Otwarte oczy”, Jednodniówka Młodej Polki, [1934].

\section{Opracowania:}

Barszczewski, Waldemar. „Kwestia parlamentarna w polskich czasopismach kobiecych w latach dwudziestych i trzydziestych XX wieku", w: Małgorzata Dajnowicz, Adam Miodowski (red.), Polityka i politycy $w$ prasie XX i XXI wieku, (Białystok: Wydawnictwo Humanica, 2016), 318-327. ISBN 978-83-946177-0-7. 
Bednarz-Grzybek, Renata. Emancypantka i patriotka. Wizerunek kobiety przełomu XIX i XX wieku w czasopismach Królestwa Polskiego, (Lublin : Wydawnictwo Uniwersytetu Marii Curie-Skłodowskiej, 2010). ISBN 97883-227-3170-3.

Chwastyk-Kowalczyk, Jolanta. „Bluszcz” w latach 1918-1939. Tematyka społeczna oraz problemy kultury i literatury, (Kielce : Wydawnictwo Akademii Świętokrzyskiej, 2003). ISBN 83-7133-212-2.

Chwastyk-Kowalczyk, Jolanta. „Próby uobywatelnienia kobiet w okresie dwudziestolecia międzywojennego na łamach "Bluszczu»", w: Małgorzata Dajnowicz, Adam Miodowski (red.), Polityka i politycy w prasie XX $i$ XXI wieku. Polityka w prasie kobiecej, (Białystok : Wydawnictwo Uniwersytetu w Białymstoku, 2019), 75-102. ISBN 978-83-7431-561-6.

Dawidowicz, Aneta. „Problematyka polityki i polityków na łamach "Głosu Kobiet", czasopisma dla kobiet wydawanego w latach 1908-1939", w: Małgorzata Dajnowicz, Adam Miodowski (red.), Polityka i politycy $w$ prasie XX i XXI wieku. Polityka w prasie kobiecej, (Białystok : Wydawnictwo Uniwersytetu w Białymstoku, 2019), 57-71. ISBN 978-83-7431-561-6.

Dołęgowska-Wysocka, Mirosława. „Tygodnik "Kobieta Współczesna” 19271934", Kwartalnik Historii Prasy Polskiej, t. 21, nr 3-4, 1982. ISSN 01372998.

Domarańczyk, Daria. Od emancypacji do feminizmu. „Ster” jako postępowe pismo kobiece przełomu XIX i XX wieku, (Łódź : Wydawnictwo Primus Verbum, 2016). ISBN 978-83-65237-19-4.

Dufrat, Joanna. „Buntowniczka w Sejmie. Parlamentarna aktywność Zofii Moraczewskiej (1873-1958)", w: Szczepan Kozak et al. (red.), Człowiek, społeczeństwo, źródło. Studia dedykowane profesor Jadwidze Hoff, (Rzeszów : Wydawnictwo Uniwersytetu Rzeszowskiego, 2014), 99-107. ISBN 978-83-7996-114-6.

Dufrat, Joanna. „Dyskusje wokół «nowego typu kobiety-obywatelki» w Drugiej Rzeczypospolitej”, w: Anna Landau-Czajka, Katarzyna Sierakowska (red.), Procesy socjalizacji w Drugiej Rzeczypospolitej 1914-1939. Zbiór studiów, (Warszawa : Instytut Historii PAN, 2013). ISBN 978-83-63352$22-6$.

Florczak, Ilona. „Socjalistka na prowincji - społeczna i polityczna działalność Zofii Moraczewskiej w Galicji (do 1914 roku)”, w: Jolanta Kamińska-Kwak, Szczepan Kozak, Dariusz Opaliński (red.), Kobieta w Galicji. 
Nowoczesność $i$ tradycja, (Rzeszów : Wydawnictwo Uniwersytetu Rzeszowskiego, 2016), 296-310. ISBN 978-83-7996-345-4.

Franke, Jerzy. Wokół buntu i pokory. Warszawskie czasopisma kobiece w latach 1905-1918, (Warszawa : Instytut Informacji Naukowej i Studiów Bibliologicznych Uniwersytetu Warszawskiego, 2000). ISBN 83-9040364-1.

Gorzkiewicz, Natalia. „Czasopismo "Bluszcz” a aktywność zawodowa kobiet w latach 1926-1928”, w: Radosław Sioma (red.), Kobiece dwudziestolecie 1918-1939, (Torun : Wydawnictwo Naukowe Uniwersytetu Mikołaja Kopernika, 2018), 71-85. ISBN 978-83-231-3861-7.

Iwasiów, Inga, Krukowska, Aleksandra, Zawiszewska, Agata (red.). Nowa Kobieta-figury i figuracje, (Szczecin : Wydawnictwo Naukowe Uniwersytetu Szczecińskiego, 2017). ISBN 978-83-7972-127-6.

Jakubiak, Krzysztof (red.). Partnerka, matka, opiekunka. Status kobiety $w$ dziejach nowożytnych od XVI do XX wieku, (Bydgoszcz : Wydawnictwo Uczelniane Wyższej Szkoły Pedagogicznej, 2000). ISBN 83-7096-346-3.

Kacperski, Kamil. „Stulecie praw wyborczych kobiet w Polsce”, Infos, nr 12, 2018, 1-4. ISSN 2082-0666.

Kałwa, Dobrochna. „Głosy kobiet w sprawie planowania rodziny w świetle prasy z lat 1929-1932", w: Anna Żarnowska, Andrzej Szwarc (red.), Kobieta i kultura życia codziennego. Wiek XIX i XX, (Warszawa : Wydawnictwo DiG, 1997), 123-132. ISBN 83-85490-94-9.

Kałwa, Dobrochna. Kobieta aktywna w Polsce międzywojennej. Dylematy środowisk kobiecych, (Kraków : Towarzystwo Wydawnicze Historia Iagellonica, 2001). ISBN 83-88737-25-2.

Kaszewski, Krzysztof. Media o sobie. Językowe elementy autopromocyjne $w$ przekazach informacyjnych prasy, radia i telewizji, (Warszawa : Wydawnictwo Naukowe Semper, 2018). ISBN 978-83-7507-214-3.

Kondracka, Mariola. Posłanki i senatorki II Rzeczypospolitej, (Warszawa : Wydawnictwo Sejmowe, 2017). ISBN 978-83-7666-473-6.

Kulak, Teresa. "Czerwone bluzki” w akcji. Krakowski Zjazd Kobiet polskich w październiku $1905 \mathrm{r}$. w walce o prawa społeczne i obywatelskie", w: Teresa Kulak, Agnieszka Chlebowska (red.), Kobiety w wojnach $i$ konfliktach polityczno-społecznych na ziemiach polskich $w$ pierwszej połowie $X X$ wieku. Wybrane zagadnienia, (Wrocław : Wydawnictwo Chronicon, 2014), 21-58. ISBN 978-83-938172-7-6. 
Landau-Czajka, Anna. „Kobiety na pograniczu polsko-żydowskim (żydowska prasa polskojęzyczna)", w: Tomasz Pudłocki, Katarzyna Sierakowska (red.), Aktywność publiczna kobiet na ziemiach polskich. Wybrane zagadnienia, (Warszawa : Wydawnictwo Neriton, 2013), 157-168. ISBN 978-83-7543-262-6.

Lisek, Joanna. „Dyskurs feministyczny w kobiecej prasie jidysz w Polsce”, Pamiętnik Literacki, z. 4, 2008, 61-77. ISSN 0031-0514.

Lizurej, Marzena. „Prasa kłamie czy wychowuje? Fenomen prasy kobiecej”, w: Witold Jakubowski, Edyta Zierkiewicz (red.), Edukacyjne konteksty kultury popularnej, (Kraków : Impuls, 2002). ISBN 83-7308-187-9.

Luksa, Katarzyna. Gabriela Balicka (1867-1962). Działalność polityczna, społeczna, naukowa, edukacyjna, (Warszawa : Wydawnictwo Sejmowe, 2017). ISBN 978-83-7666-506-1.

Łozowska-Marcinkowska, Kamilla. Sprawy niewieście. Problematyka czasopism kobiecych Drugiej Rzeczypospolitej, (Poznań : Wydawnictwo Poznańskie, 2010). ISBN 978-83-7177-722-6.

M.Z. [Maria Zawialska]. „Prasa kobieca”, w: Julian Maślanka (red.), Encyklopedia wiedzy o prasie, (Wrocław-Warszawa-Kraków-Gdańsk : Zakład Narodowy im. Ossolińskich, 1976).

Maj, Ewa. „Kobieta wobec polityki; strategie tożsamościowe w publicystyce tygodnika "Na Posterunku" (1917-1919)", w: Małgorzata Dajnowicz, Adam Miodowski (red.), Polityka i politycy w prasie XX i XXI wieku. Polityka $w$ prasie kobiecej, (Białystok: Wydawnictwo Uniwersytetu w Białymstoku, 2019), 43-56. ISBN 978-83-7431-561-6.

Maj, Ewa. „Parlamentarzystki Narodowej Demokracji”, w: Urszula Kozłowska, Tomasz Sikorski, Adam Wator, Obywatelki na obcasach. Kobiety $w \dot{z} y c i u$ publicznym (XIX-XXI w.), (Radzymin-Warszawa : Wydawnictwo von Borowiecky, 2016), 131-146. ISBN 978-83-60748-87-9.

Maj, Ewa. „Politycy - publicyści prasowi w Polsce”, w: Małgorzata Dajnowicz, Adam Miodowski (red.), Polityka i politycy w prasie XX $i$ XXI wieku, (Białystok : Wydawnictwo HUMANICA, 2016), 167-182. ISBN 978-83946177-0-7.

Pisarek, Walery. „Perswazja - jak ją widza, jak ja pisza”, w: Katarzyna Mosiołek-Kłosińska, Tadeusz Zgółka (red.), Język perswazji publicznej, (Poznań : Wydawnictwo Poznańskie, 2003), 9-17. ISBN 83-7177-257-2. 
Pisarek, Walery. Polskie słowa sztandarowe i ich publiczność, (Kraków : Universitas, 2002). ISBN 83-242-0003-7.

Plach, Eva. „Feminizm and Nationalism on the Pages of Ewa: Tygodnik, 1928-1933", Polin. Studies in Polish Jewry, vol. 18, 2005, 241-262. ISSN 0268-1056.

Sokół, Zofia. „Z badań nad polską prasa kobiecą w latach 1818-1939”, Kwartalnik Historii Prasy Polskiej, t. 22, nr 3, 1983, 5-12. ISSN 0137-2998.

Szyszko-Trojanowska, Joanna. "Nasze zdobycze i nasze zaniedbania”Cecylia Walewska o instynkcie społecznym", w: Agata Siwiec, Joanna Szyszko-Trojanowska, Agata Zaliszewska (red.), Modele aktywności politycznej Polek od XIX do XXI wieku, (Szczecin : Wydawnictwo Naukowe Uniwersytetu Szczecińskiego, 2018), 41-56. ISBN 978-83-7972-169-6.

Szyszko-Trojanowska, Joanna. „Równouprawnienie sportowe a kształtowanie się nowego typu kobiety sportsmenki w świetle międzywojennych magazynów dla kobiet - "Bluszczu» i "Startu»", w: Inga Iwasiów, Aleksandra Krukowska, Agata Zawiszewska (red.), Nowa Kobieta - figury i figuracje, (Szczecin : Wydawnictwo Naukowe Uniwersytetu Szczecińskiego, 2017), 287-311. ISBN 978-83-7972-127-6.

Śliwa, Michał. „Wzorzec osobowy kobiety - socjalistki w Polsce”, w: Anna Żarnowska, Andrzej Szwarc (red.), Kobiety i edukacja na ziemiach polskich $w$ XIX $i$ XX wieku, t. 2, cz. 1, (Warszawa : Instytut Historyczny Uniwersytetu Warszawskiego, 1995), 225-239. ISBN 83-85490-41-8.

Tetelowska, Irena. Szkice prasoznawcze, wybór rozpraw i artykułów Paweł Dubiel, Walery Pisarek, (Kraków : Ośrodek Badań Prasoznawczych RSW "Prasa", 1972).

Wojtak, Maria. „Interakcyjny styl komunikowania w prasie kobiecej”, w: Eadem, Rozłożone gazety. Studia z zakresu prasowego dyskursu, jezyka i stylu, (Lublin : Wydawnictwo Uniwersytetu Marii Curie-Skłodowskiej, 2015), 107-122. ISBN 978-83-7784-660-5.

Wyder, Grażyna. „Wielkopolskie działaczki w ruchu narodowo-demokratycznym na terenie Poznańskiego na przełomie XIX i XX wieku. Szkic do działalności politycznej kobiet”, Czasopismo Naukowe Instytutu Studiów Kobiecych, nr 1, 2017, 58-67. ISSN 2451-3539. 